\title{
Are We In This Together?: The Polarisation of the British Society and the Marginalisation of Otherness in Ali Smith's Seasonal Quartet
}

\section{Introduction}

Ali Smith's seasonal quartet was sketched as a bold and arduous undertaking on a number of levels. The most fundamental challenge was its sheer timeline: the novelist planned to write and publish four books in four consecutive years. The joint efforts of the writer and the publisher were rewarded with success (one-year delay of the third instalment is negligible). Then came the issue of synchronicity: the cycle was meant to be set mainly at the time of its composition and to actively respond to the ongoing cultural and political developments. Smith triumphs here as well: the books are well up to date. Although Donald Trump is not yet elected president when Autumn is published, Winter mentions his loathsome speech to the Boy Scouts in West Virginia, and Summer hints at the possibility of his impeachment commented in the media. A late-middleaged male protagonist of Spring undertakes soul-searching when he learns about the \#MeToo movement, and the characters of Summer wear facemasks and complain about the lockdown during the Covid-19 pandemic. Yet Smith's primary concern is obviously Brexit: the novels become a chronicle of the state transformation from the 2016 referendum to the UK's effective departure from the $\mathrm{EU}$ in 2020 , portraying Britain anguished by internal conflicts, xenophobia and racism, populist political campaigns and economic problems. This forthright topicality leads to the third challenge posed by the four-book endeavour: 
Smith must beware of succumbing to simplistic documentary models, which could compromise the artistic qualities of her prose. Yet she is not disappointing in this respect, either; the seasonal quartet goes beyond its primary political focus, making references to wider themes, including the quandaries of human condition related to the climatic changes or to new technologies. Centred on contemporaneity, the novels are aware that our identity is created mostly by our past: memories, history and myth.

Each of the four novels comprising the cycle appears to be relatively independent: they have individual plot lines and they seem to centre on different characters. Yet on reflection the overall pattern emerges: most main protagonists are, in fact, quite closely related, but the connections are intricately woven into the narrative fabric and we can fully decipher Smith's subtle hints only after reading the last instalment. Then, there is a distinct linking pattern in intertextuality: each novel takes as its point of reference a Shakespeare's late romance-The Tempest, Cymbeline, Pericles and The Winter's Tale respectively-and a Dickens's novel-A Tale of Two Cities, A Christmas Carol, Hard Times and David Copperfield. Each one centrally introduces a female British (or working in Britain) artist-a painter Pauline Boty, a sculptor Barbara Hepworth, a visual artist Tacita Dean and a filmmaker Lorenza Mazzetti. All four books also share the same general narrative design: each is a charade which we unravel gradually, as we construct the frame of the story, putting chronologically dislocated episodes in order and decoding dissipated ambiguities. They are conceived in the form of a patchwork, joining together ostensibly disparate elements, a polyphonic tumult of mutually overlapping discourses, reflections, conversations, dream sequences, ubiquitous puns, surreal or magic realist passages, ekphrastic fragments and snippets from books quoted by protagonists. This disjointed, fragmentary and heteroglossic character of the cycle is noted by the reviewers and critics. James Ley mentions the "friction created by [Smith's] temporal manipulations ... and her ability to move between fictional modes," suggesting that that her novels create "meaning from juxtapositions and parallels in a way that suggests reality can be reordered and understood in a multitude of ways" (Ley). Faced with its multi-layered structure and jumbled interconnections, the readers identified in the seasonal quarter the quality of a collage, especially because the first instalment, Autumn, introduces the work of Pauline Boty, whose pictures used this very technique. For Petra Rau, reading this novel is "like a long and slow contemplation of an enormous collage of scenes and images about our moment," particularly because Autumn, with "its peculiar loops and cycles," problematises the "subjective experience of time and its unknowable import" (Rau 42). 
The times experienced by the protagonists of the cycle are the harrowing years of the Brexit process. Smith's four novels fall into Kristian Shaw's category of "BrexLit," i.e. "fictions that either directly respond or imaginatively allude to Britain's exit from the Eu, or engage with the subsequent socio-cultural, economic, racial or cosmopolitan consequences of Britain's withdrawal, ... addressing fears surrounding national identity and cultural change in post-Brexit Britain" (Shaw 18). Ali Smith's keen involvement in pressing political issues of the day extends to her other major concern in the quartet: the regenerative potential of human artistic endeavours which gives us the capacity to persevere and cling to life. When she has one of the characters of Spring, Paddy, announce: "There's ways to survive these times ... and I think one way is the shape the telling takes" (A. Smith 2019: 21), she expresses a more general observation on human nature. In Ley's words, the novelist's "response to the darkness of the times" relies on "a belief in the priority of art, a belief that we are-fundamentally, constitutively-art-makers, storytellers, fashioners of our own worlds" (Ley).

In this article I intend to examine how Ali Smith's seasonal quartet engages with the issue of Brexit, becoming the chronicle of a grinding cultural process and critically confronting the transformation of the British nation. I am going to look at various psychological factors related to the polarisation of the British society caused by Brexit, and investigate Smith's presentation of the way in which the populist propaganda of menace leads to marginalising Otherness. The discussion will use the nomadic theory developed by Rosi Braidotti. As Braidotti explains, nomadic thought, which she develops from Deleuze and Guattari's works on capitalism, relies on "a nonunitary philosophy of the subject," attempts to "deterritorialize stable identities" (Braidotti 2011: 209), and ventures to "free the process of subject formation from the normative vision of the self" (Braidotti 2011: 83). Following Foucault's founding works on relations between power and knowledge, nomadic theory also extends to analyse the practices that regulate human structures of thinking and consequent scientific norms and patterns. The approach I assume focuses especially on Braidotti's "postnationalist vision of European subjectivity based on the critique of Eurocentrism" (Braidotti 2011: 249), which becomes part of her posthuman project and articulates the subject dynamically, through the process of "becoming-nomad" of Europe:

The becoming-nomad of Europe entails resistance against nationalism, xenophobia and racism, bad habits of the old imperial Europe. As such, it is the opposite of the grandiose and aggressive universalism of the past, which is replaced by a situated and accountable perspective. It embraces a new political and ethical project, by taking a firm stand 
also against the 'Fortress Europe' syndrome and reviving tolerance as a tool of social justice... The project of developing a new kind of post-nationalist nomadic European identity is certainly challenging in that it requires dis-identification from established, nation-bound identities. (Braidotti 2013: 53-44)

I attempt to demonstrate how Braidotti's rejection of methodological nationalism becomes useful in reading Ali Smith's seasonal quartet as a literary approach to Brexit.

\section{Brexit and Postcolonial Melancholia}

Claiming that the results of the June 2016 referendum were unexpected would be a serious understatement. Suffice it to say that when the polls closed even Nigel Farage, leader of the United Kingdom Independence Party, publicly admitted defeat. The Leave vote stunned the political establishment, academic experts, media commentators and general public not just in Britain, but all over Europe. Yet the analyses published in the ensuing months indicated that Brexit was, in truth, the result of numerous social and cultural processes which culminated after decades and are rooted deeply in the history of the nation. The surge of sympathy for right-wing nationalist separatism in the immediate years preceding the referendum gave rise to resentment against open labour market and trans-European immigration. The sources of this widespread Euroscepticism in Britain entail, as Kevin O'Rourke notes, both an economic and a cultural dimension: whereas some see Brexit as "the product of globalization, or technological change, or other impersonal economic forces that are damaging vulnerable communities," others seek its reasons in "racism, xenophobia, nationalism and other forms of extreme cultural conservatism" (O'Rourke 177). No matter which side you supported, the officially proclaimed motivations were always high-minded:

Leave voters were concerned about immigration along with ... control, sovereignty and country, [while] Remainers ... were overwhelmingly concerned about the economic consequences of Brexit along with its impact on employment and social rights. (Evans, Menon 76)

Many studies also demonstrated that voters' motivations were influenced by several key socio-cultural factors: Brexit supporters were more likely to be socially conservative, less educated, older, economically disadvantaged, and 
living in the Midlands, the North East, Yorkshire and Eastern England, while its opponents were, by and large, socially liberal, university-educated, younger, more prosperous, inhabitants of London, other major cities, as well as Scotland and Northern Ireland (Evans, Menton 74, 77, 83-85; Norris, Inglehart 375-378). Also, those who voted Leave were mostly white and they considered themselves rather English than British (Hughes 95; Norris, Inglehart 375). It is necessary, then, to see Brexit as a consequence of an extended process driven by long-established affinities, suspicions, concerns and anxieties, or, in fact, as Brian M. Hughes puts it, "a myriad of psychological factors as experienced across many social groups" (Hughes 3 ).

Hughes further argues that Brexit is often described in a psychiatric language, as "madness" (Hughes 111), "mental disorder," "national masochism and self-harm" (Hughes 113). He states that the advocates of each side are delineated by their opponents in pathological terms: those from one camp are designated as "Remoaners," which suggests their "chronically disordered mood," while those from the other are labelled as "Brextremists," which indicates their sociopathic constitution (Hughes 2). Yet academic psychological explanations of the phenomenon are not symmetrical: most of them discern a pathological disposition in Brexit supporters. Fintan O'Toole, for instance, sees British Euroscepticism as rooted in the old grievances against the Germans, and claims that the "imaginary existential struggle" which started in the 1970s is perceived as "a hallucinatory reprise" of ww2 (O’Toole). He argues that it has not been rare among the British isolationists to perceive the $\mathrm{EU}$ as a continuation of an earlier project supposed to unite the continent, that of Hitler's Reich (O'Toole). O'Toole further postulates that the lingering masochistic national fantasy of defeat, dubbed by him "the Dunkirk spirit," pervaded numerous Brexit campaign debates. Eurosceptics see the apex of British national humiliation, the critic argues, in the fact that their country has gone "straight from being the colonizer to being the colonized"; they imagine the former greatest colonial power as "annexed by the European superstate" (O'Toole). The masochistic "cult of heroic failure" (O'Toole), recognized as an important psychological factor determining British approaches to the EU membership, relates to Paul Gilroy's notion of "postcolonial melancholia," diagnosed by him in the British nation. Gilroy claims that the British have suffered a "multilayered traumaeconomic and cultural as well as political and psychological-involved in accepting the loss of the Empire" (Gilroy 108) and the recent existence of the nation "has been dominated by an inability ... to . . mourn the profound change in circumstances and moods that followed the end of the Empire and consequent loss of imperial prestige" (Gilroy 98). Robert Saunders notes the 
crucial position of "postcolonial melancholia" in the discourses employed in the 2016 Brexit debate, asserting that the discussion evoked "powerful emotions of fear, loss and betrayal, with deep roots in British history" and addressed the anxieties related to present-day Britain's position in the world (Saunders 1141). Saunders recalls press reports following the referendum results, discerning in them reverberations of nostalgic longing for glorious colonial past. He points out that the ideological foundations of Brexit are indebted to Enoch Powell, "the godfather of the Eurosceptic Right" (Saunders 1161), and concludes that the Leave campaigners seek the reinstatement of the idealized vision of Britain as a global power, marginalising all unsettling elements of imperial history (Saunders 1160, 1146). As Gilroy claims, the unresolved trauma, aggravated by the fact that the often uncomfortable and shameful history of the Empire was not "work[ed] through [but] diminished, denied, and . . actively forgotten" (Gilroy 98), has produced "an extensively fragmented national collective" instead of o homogeneous nation (Gilroy 111).

\section{Polarisation, Populism and Post-Truth Propaganda}

The EU referendum did not cause the split in the British society; in fact, it was caused by long-standing internal conflicts and incompatibilities which it actually brought to light. As Zadie Smith puts in, a "useful consequence of Brexit is to finally and openly reveal a deep fracture in British society that has been thirty years in the making" (Z. Smith 27). On the one hand, some form of internal dissection within a society is customary and inevitable: in Homi K. Bhabha's opinion, it is only natural that we perceive any nation as "split within itself, articulating the heterogeneity of its population," since it only displays "antagonistic authorities and tense locations of cultural difference" in the nation's selfhood (Bhabha 212). Yet, on the other hand, if this breach is pathologically excessive, and "extreme inequality fractures communities," it is just a question of time when "the cracks gape so wide the whole edifice comes tumbling down" (Z. Smith 29). This is clearly the case in Ali Smith's vision of the post-referendum Britain, which, as other works of BrexLit, portrays "community split between hospitality and hostility" (Shaw 22).

The polarisation within the British nation is evident in all four novels of the seasonal quartet. As the first instalment, Autumn, demonstrates, severe animosities are raised immediately after the referendum. Elisabeth's mother, Wendy, complains that "half the village isn't speaking to the other half of the village" (A. Smith 2016: 54). The percentage is vital: the foul rift in the nation is all the more troublesome as it divides it almost exactly into two equal parts. 
The 2016 poll results show that the Leave vote won merely by the margin of 1.3 million, which comprises around $2 \%$ of the uK population: it would be enough to reverse the voting of only $1 \%$ of people to change the results (see, e.g., Hughes 16). Smith's novels dramatize this awkward polarization not by numbers, but in micro-scale, by means of showing divided families. Winter presents a conflict between two late-middle-aged sisters who vote differently; in Summer, a teenage sister and brother quarrel about Brexit. Their mother, whose political disagreement with her husband is the major reason of their separation, laments that the voting "split her own family as if with cheesewire, sliced right through the everyday to a bitterness nobody knew what to do with, one so many people used to hurt people with" (A. Smith 2020: 312). Excessive reactions in such conflicts are routine: in his discussion of Brexit psychology, Hughes reports scientific data proving that members of polarised groups usually adopt "exaggerat[ed] opinions," which, in turn, "leads to sentiment escalation" (Hughes 87). Taking one of the sides also seems inevitable: a person experiencing a polarising crisis "will end up at one pole or the other" (Hughes 122). Smith renders this bipolarity in an oft-quoted fragment from Autumn:

All across the country, people felt it was the wrong thing. All across the country, people felt it was the right thing. All across the country, people felt they'd really lost. All across the country, people felt they'd really won. All across the country, people felt they'd done the right thing and other people had done the wrong thing. ... All across the country, the country was divided, a wall there, a line drawn here, a line crossed there. (A. Smith 2016: 60-61)

This escalation of sentiment towards Brexit, which contributed to fragmenting the "national collective," also translated into the voting motivations. Evans and Menon argue that most voters did not carefully consider the possible positive or negative outcomes of leaving the European Union, but made up their minds intuitively: in the perception of the British citizens "EU membership was either a good thing or a bad thing. Nuanced arguments about its impact in specific areas of British life had little or no influence on [their] opinions" (Evans, Menon 71).

This minimal impact of "nuanced arguments" on the opinions of the general public is largely caused by the populist discourses profusely produced in recent years by politicians to manipulate the masses. The campaigns preceding the Brexit referendum and the presidential election in the United States in 2016 were so highly charged with psychologically tailored affective messages that Oxford 
Dictionaries has proclaimed the adjective designating them, "post-truth," its international word of the year. The dictionary defines post-truth as "relating to or denoting circumstances in which objective facts are less influential in shaping public opinion than appeals to emotion and personal belief" (Flood). The present-day political success of populist manipulation not only eventuated in Brexit and Donald Trump's victory, but it can be seen, as O'Rourke observes, in the rising support, or sometimes the arrival to power, of populist parties in other countries, including France, Italy, Austria, Hungary and Poland (O'Rourke 176). In the opinion of commentators, the British referendum campaign well deserved the label of a "post-truth" debate, as especially the Leave camp employed a number of economic and social concerns in order to evoke the general frustration, marginalising the authority of experts' opinions and "raising the prospect of a more visceral politics in place of the evidence-, or at least expertise-, based approach," which was a British standard since New Labour times (Evans, Menon 68). Norris and Inglehart point out that undermining the counselling authority of experts remains a routine strategy of populist propagandists, who declare that political and moral reason resides only with the masses, and who present the "voice of ordinary citizens . . . as the only 'genuine' form of democratic governance even when at odds with professional judgments-including those of elected representatives and judges, scientists, scholars, journalists and commentators" (Norris, Inglehart 5). In her emotional address following Trump's election, Braidotti expresses a highly critical opinion about "post-truth" debates, stating that "right-wing populism ... is a nauseating form of political manipulation" and that we are manipulated by political regime "where factual truths play no role at all: in the Brexit, as in the Trump campaign, people were shamelessly lied to. What mattered most to them was the expression of negative emotions and violent passions" (Braidotti 2016). In fact, the post-truth manipulative discourse is a clear continuation of colonial racist discourse, which, as Bhabha reveals, "inscribes a form of governmentality that is informed by a productive splitting in its constitution of knowledge and exercise of power, ... a form of governmentality in which the 'ideological' space functions in more openly collaborative ways with political and economic exigencies" (Bhabha 118-119).

This post-truth dimension of populist governmentality is critically addressed by Ali Smith's novels. Spring opens with a passage that re-imagines the imperious propagandist discourse of the right-wing nationalistic media, which structure the reality. Their headlines and news bulletins amalgam into a stream of emotive evocation: "Ban New Migrants Gunships To Stop Migrants How Many More Can We Take Bolt Your Doors Hide Your Wives we want zero 
tolerance" (A. Smith 2019: 4). In Winter, Charlotte feels resentful about harrowing images-"Refugees in the sea. Children in ambulances. Blood-soaked men running to hospitals or away from burning hospitals carrying blood-covered children. Dust-covered dead people by the sides of roads. Atrocities. People beaten up and tortured in cells" (A. Smith 2017: 29-30) - presented in the media with a clear intention of terrifying the audiences. When she concludes that "pre-planned theatre is replacing politics ... and [people] are propelled into shock mode, trained to wait for whatever the next shock will be, served up shock on a 24-hour newsfeed" (A. Smith 57), her partner, Art, dismisses it as conspiracy theory. Yet, other characters of Smith's quartet share Charlotte's apprehension and distrust towards the populist propaganda fed into them. In Autumn, Wendy resignedly confesses to her daughter:

I'm tired of the news. I'm tired of the way it makes things spectacular that aren't, and deals so simplistically with what's truly appalling. I'm tired of the vitriol. I'm tired of the anger. I'm tired of the meanness. I'm tired of the selfishness. I'm tired of how we're doing nothing to stop it. I'm tired of how we're encouraging it. ... I'm tired of lying governments. I'm tired of people not caring whether they're being lied to any more. I'm tired of being made to feel this fearful. (A. Smith 2016: 56-57)

Even a teenage character of Summer, Sacha, is aware that "everyone and everything on TV is like someone wearing a mask" (A. Smith 2020: 15). Several passages of Spring, which the reader finally identifies as having been written by the twelve-year-old Florence, strive to tear off this mask, verbalising the suppressed manipulative intentions of the right-wing media in the form of straightforward declarations. The novel begins with an emphatic reversal of the statement from Dickens's Hard Times - "Now what we don't want is Facts"-and reinstates it with an explicit populist announcement: "What we want is people in power saying the truth is not the truth" (A. Smith 2019: 3). Florence's writing exposes the clear-cut objectives of cynical post-truth rhetoric- "We need news to be what we say it is. We need words to mean what we say they mean. We need to deny what we're saying while we're saying it" (A. Smith 5)-especially its intention to fabricate menace - "What we need is panic we want subconscious panic" (A. Smith 4). The authority that the society attaches to the media allows the hegemonic propagandists to create a discursive reality and enslave the minds of its more oblivious denizens. In this respect, Smith's novels evoke Orwell's representation of the subjugating powers at work in totalitarian societies. Robert, Sacha's brother, recognises the Orwellian quality of the reality, 
when he asserts that contemporary people "all live in an open prison now and ought just to admit it and stop imagining [they] don't" (A. Smith 63).

This is not to say that Ali Smith postulates we all live in a totalitarian world. Yet, she wishes to bring attention to the threats following the crisis of Western liberal democracy. If we accept the image of a threatening reality propagated by the media as true, we naturally seek protection. Since our vulnerability is best remedied by "high walls" and "strong leaders," we lean right, driven by the populist rhetoric which "seeks to corrode faith in the legitimate authority of elected representatives in liberal democracies" (Norris, Inglehart 6-7). Alluding to Nietzsche's and Derrida's conviction of the suicidal disposition of the democratic system, Braidotti bitterly remarks that "democracy in itself is not enough to save us from its electoral majority," especially when sabotaged by sustained efforts of populism (Braidotti 2016). She is disheartened by the general mistrust of representative democracy, which enables populists to put the referendum to "manipulative use ... as a political instrument" (Braidotti 2016). The abuse of this form of application of vox populi was widely commented after the British 2016 polls, also by Zadie Smith, who holds that a "referendum magnifies the worst aspects of an already imperfect system-democracy-channelling a dazzlingly wide variety of issues through a very narrow gate" (Z. Smith 24).

A central aim of orchestrating "subconscious panic" by the conservative media is to justify various practices of restriction and segregation imposed on "Others" with the need to defend the society's well-being. Braidotti denounces devious actions of right-wing politicians, such as Donald Trump and Boris Johnson, who "only 'empathise' with the pain and despair of their electorate to the extent that they encourage them to scape-goat their built-up anger onto women, LBGTQ, migrants, foreigners, asylum-seekers and other figures of despised 'otherness"' (Braidotti 2016). Similarly, in their analysis of populist rhetoric, Norris and Inglehart point out that authoritarians are "intolerant of out-groups, rejecting minorities seen as challenging conventional norms, whether the groups are defined in terms of race, ethnicity, nationality, religion, gender, sexuality, or ideology," and that this rhetoric "evokes feelings of disgust and anger against out-group scapegoats, who are blamed for socio-economic problems" (Norris, Inglehart 73). Naturally, such a form of scapegoating is not a new strategy of psycho-social manipulation: it was routinely used by totalitarian governments. This connection is also recognised by Smith's characters: in Winter Iris observes that the British government is "using people's rage for its own political expediency" and concludes that it is "a grand old fascist trick" (A. Smith 2017: 56). 


\section{Fencing the Other}

As Ali Smith's seasonal quartet illustrates, the hostile propaganda of the conservative media may often prove effective on the British society. Iris's sister, Sophie, strongly influenced by the right-wing tabloids, believes that the position of the UK citizens is threatened by migrants who are "coming here because they want our lives" (A. Smith 2017: 206). The manipulative rhetoric of menace utilises the logic expounded by Achille Mbembe: "The security state thrives on a state of insecurity, which it participates in fomenting and to which it claims to be the solution. If the security state is a structure, the state of insecurity is a kind of passion, or rather an affect, a condition, or even a force of desire" (Mbembe 54, emphasis original). Following the footsteps of Bhabha, Mbembe explains the quandaries of the hegemonic subject through psychoanalysis: his contention is that the subject deluded by fantasies of peril may either choose "to turn back on itself in the hope of protecting itself from external danger," or to go "outside of itself to confront the windmills of its imagination that henceforth assail it." The subject's desire attempts to "conquer [the] terrifying object," but because this object does not exist, "desire must continually invent it" (Mbembe 43). This reasoning also relates to Braidotti's conviction (based on Deleuze and Guattari's standpoint) that "the prerogative of being dominant means that a concept gets defined oppositionally, by casting outward upon others the marks of oppression or marginalization," and that, consequently, "the invisibility of the dominant concepts is also the expression of their insubstantiality-which makes them all the more effective in their murderous intents toward the many others on whose structural exclusion they rest their vampirelike powers" (Braidotti 2011: 251). In the contemporary British context, this translates into the assumption that at the centre of British national identity is a void, and, just as the British empire was erected on the economic exploitation of colonies, so does the British postcolonial identity, enfeebled by melancholia, strive to regain its vigour by victimising others.

Ali Smith's novels show Brexit as an appropriate opportunity for such acts of hostility. Autumn depicts a village where someone has written "GO HOME" across the front wall of a house of migrants. In Summer, Sacha's Muslim friend's mother is ridiculed in the street by a man inspired by Boris Johnson Evening Standard article which compared veiled women to letterboxes. The novel also mentions a dubiously legal process of deporting homeless people on buses to constituencies where MPs are not Tories and an English teacher getting hit with a brick by a parent angry for teaching his kid apparently "foreign" words, such as "rancour" or "Bildungsroman." Migrants and refugees in Spring feel 
that they "moved from one invisibility to another"; they are marginalised and objectified in the country where they sought help. Without permission to work or study, with an uncertain residency status, they feel that their personhood is only guaranteed by a document issued by British state officials. The novel's passage imagining right-wing media discourse openly declares: "We want the people we call foreign to feel foreign we need to make it clear they can't have rights unless we say so" (A. Smith 2019: 3).

The alienation and objectification of "foreigners" is achieved by means of isolating them in enclosed and well-guarded detention centres. Smith's tetralogy depicts the gradual process of their development in Britain. In Autumn, Elisabeth and her mother come across a mesh wire fence crowned with razor wire and CCTV cameras, newly raised in the middle of an empty field. Its purpose and administrators are unknown, yet the women are prohibited from filming it on the grounds of national security measures. In 2016, the fence still has mostly metaphorical meaning, standing, as Shaw puts it, for "a territorial reminder of a nation divided and ... an allusion to the enforcement of toxic anti-immigration policies on the horizon" (Shaw 22). ${ }^{1}$ Yet three years later, in 2019, in Spring, such enclosed areas are now actively functioning immigrant detention centres. In the quartet's final instalment, Summer, Grace encounters in the countryside a similar fence, which a woman walking her dog calls "a government place for people who don't belong in this country" (A. Smith 2019:310). The woman then throws a plastic bag with her dog's shit so that it hangs torn over the fence and walks way, and Grace never learns if her action was caused by animosity against immigrants or censure against the government strategy of their incarceration. Smith leaves both options open for the reader, yet again accentuating the polarisation of the British society.

John Masterson suggests that Ali Smith underlines the weight of detention centres, along with their "carceral politics and obfuscatory rhetoric," as "chronotopes" of the times which position otherness in contradictory, paradoxical vacillation between invisibility and hypervisibility (Masterson 357). In Braidotti's understanding, the "proliferation of detention and high-security camps and prisons within the once civic-minded space of European cities is an example of the inhuman face of Fortress Europe," where such institutionary establishments of objectification function as "the undignified monuments of posthuman inhumanity" (Braidotti 2013: 127). Arguably, British internment camps for immigrants fulfil the national fantasy inspired by the desire for an enemy, and the enemy's separation, revealed by Mbembe:

1 In her 2016 essay, "Fences: A Brexit Diary," Zadie Smith also employs the figurative use of fences to mark the internal divisions within the British nation (cf. Z. Smith 20-27). 
A separation wall is supposed to resolve a problem of excess of presence, the very presence that some see as the origin of situations of unbearable suffering. ... This also means accepting that there is nothing common to be shared between us and them. . . Everywhere, the building of concrete walls and wire fences and other "security barriers" is in full swing. Alongside the walls, other security structures are emerging: checkpoints, enclosures, watchtowers, trenches, all manner of demarcations that in many cases have no other function than to intensify the enclaving of entire communities, without ever fully succeeding in keeping away those considered a threat. (Mbembe 43)

Yet again, the isolation of the allegedly menacing others facilitates the oppositional fabrication of the collective psyche of the British nation.

The inmates of British detention centres are objectified not merely through isolation, but also through dehumanising treatment. Ali Smith presents this aspect in Spring, with Brittany, a young girl from a poor family, who works as a "DCO in a UK IRC" (A. Smith 2019: 149). A DCO is a Detention Custody Officer, and an IRC is an Immigration Removal Centre; this officialese is supposed to elevate their status, especially in contrast with detainees, who are derogatorily dubbed "deets" by the guards. The inmates are brought usually at night, in vans with blacked out windows; the families are separated and there is a weight limit for personal possessions. The conditions of the centres resemble those in prisons: the detainees are allowed to roam the premises but are locked up for the night. The cells do not offer privacy: the beds are not separated by any screens from the toilets, which are dirty and have to lids. Medical assistance is scarce: a Kurd suffering from cancer is administered only paracetamol, and it is not available at weekends. Alarmingly, some forms of human rights abuse are not induced by the inhumanity of the system, but stem from the spontaneous brutality of the DCOs: deets are frequently mocked and abused verbally; physical coercion and constraint are used; Brittany learns "to talk weather with other DCOs while they're holding someone in headlock or four of you are sitting on someone to calm him" (A. Smith 2019: 166).

\section{Being in This Together}

The nomadic theory of the subject, as Braidotti proposes, is based on the critique of Eurocentric universalising and normative philosophy, consciousness and morality. She calls for "a collectively assembled, externally related, and multilayered subject," which contradicts and sabotages "the established view of the European subject of knowledge" (Braidotti 2011: 240). Even a few years 
before Brexit, in 2011, Braidotti discerns the resurgence of "imperial, fascistic, and undemocratic tendencies" in the European societies, which affect "the fate of migrants, refugees, and asylum seekers who bear the brunt of racism in contemporary Europe" (Braidotti 2011: 217-218). At the same time, she believes in the "progressive potential" of the European Union, hoping it can become "a site of possible political resistance against nationalism, xenophobia, and racism, bad habits that are endemic to the old imperial Europe" (Braidotti 2011: 239, 243). In order to achieve this, the Eu needs a new agenda, a "new mission," which "entails the criticism of narrow-minded self-interests, intolerance, and xenophobic rejection of otherness" (Braidotti 2011: 218). Braidotti certainly remains aware that the construction of a new, transformed European identity, which would produce a democratic multicultural space, is a highly problematic project, as it demands, on a general level, the renegotiation of power relations between member states and within them, and, on an individual level, the disconnection of nationality, citizenship and national identity (Braidotti 2011: 239-240, 258). Conservative powers of opposition to this post-nationalist vision of nomadic identity, which strive to defend "Fortress Europe," are still at work. Their activity translates into the persisting alienation and oppression of otherness. In her 2016 text addressing the results of the Brexit referendum and the election of Trump, Braidotti tries to envisage possible forms of resistance against the "paranoid rhetoric of our post-truth democratic leaders," possible actions which could help us "construct affirmative ethical and political practices" (Braidotti 2016). Drawing from her ideological catchphrase "we are in this together," which she usually uses in an ecosophical sense, she fearlessly concludes that "We need to re-radicalise ourselves" (Braidotti 2016).

Ali Smith's seasonal quartet attempts to retain some optimism about Britain's future by means of presenting characters who struggle to "be in this together." One of them is Winter's Iris, a perennial activist, who in the 1980 os chained herself to the fence in Greenham Common military base, fought for thirty years for environmental issues, ${ }^{2}$ and in the late 2010 s helped Syrian refugees in Greece. Iris has a cameo performance in Summer: she helps to organise the release of fifteen people from the detention centre and to provide housing for them. Another one is Florence, from Spring, a girl who "magically" persuades an IRC head to arrange a thorough toilet cleaning operation in the centre. In Spring and Summer we also read about an underground community of activists who help immigrants outwit the security state.

2 An important dimension of Ali Smith's quartet is "being in this together" also in an environmental sense. This, however, lies beyond the scope of my discussion. 
Autumn features a scene in which the protagonist's mother, Wendy, infuriated by the news that the government is cutting funding for houses for asylum seekers' children and plans to put them in high-security camps, which are "doubly not fit for the kids" (A. Smith 2016: 255), "re-radicalises herself" and hurls a stockpile of objects bought in an antique shop at the detention centre fence, "bombarding that fence with people's histories and with the artefacts of less cruel and more philanthropic times" (A. Smith 255). This symbolic act of protest expresses, as Shaw puts it, "resistance to borders both figurative and corporeal, both internal and external to the nation" (Shaw 23). In a more general sense, though, it also represents Ali Smith's involvement in a political and cultural debate raised by Brexit. Her engagement materialises through collaboration with the project "Refugee Tales", in which "writers and actors lend their words and voices to asylum seekers, refugees and people in indefinite detention" ("Refugee Tales"). Smith's artistic contribution is her four seasonal novels, which are also "bombarding that fence" of British institutionalised xenophobia "with people's histories," through interwoven narratives of various characters' fates, and "with the artefacts of less cruel and more philanthropic times," through intertextual and ekphrastic references to art.

Paradoxically, by voting to leave the European Union, the British placed their country within a well-established, conservative "Fortress Europe," which defies the nomadic identity open to otherness. Ali Smith's quartet of seasonal novels, published year by year successively, is an artistic chronicle of Brexit, relating the process of socio-cultural change in the $\mathrm{UK}$. Smith's allusions to the events from the past and an apt choice of intertextual references allow the reader to trace various historical and psychological factors that account for the present-day state of the British mind. By revealing the mechanisms of populist propaganda of menace and post-truth manipulation exercised by the media, her novels explain the processes that have led to the polarisation of the British society. Many British are filled with postcolonial melancholia and xenophobia. Yet there are also those who are more likely to embrace Braidotti's nomadic identity and "be in this together":

Was being on this earth really all about who owned a tree in a garden? About whether it gave you satisfaction and pleasure and fulfilment when you looked at a tree because it was yours, but when you thought it wasn't yours you longed to remove the tree? (A. Smith 2020: 313, emphases original) 


\section{| Works Cited}

Bhabha, Homi K. The Location of Culture. London: Routledge, 2007.

Braidotti, Rosi. Nomadic Theory: The Portable Rosi Braidotti. New York: Columbia UP, 2011.

---. The Posthuman. London: Polity, 2013.

---. “Don’t agonise, organise!” Il Manifesto: Global Edition. 14 November 2016. https://global.ilmanifesto.it/dont-agonise-organise/. Accessed 20 April 2021.

Evans, Geoffrey, and Anand Menon. Brexit and British Politics. Cambridge: Polity, 2017.

Flood, Alison. "Post-truth' named word of the year by Oxford Dictionaries." The Guardian. 15 November 2016, https://tinyurl.com/h3yjdrea. Accessed 20 April 2021.

Gilroy, Paul. After Empire: Melancholia or Convivial Culture? Abington: Routledge, 2004.

Hughes, Brian M. The Psychology of Brexit: From Psychodrama to Behavioural Science. Basingstoke: Palgrave Macmillan, 2019.

Ley, James. "Brexit, Pursued by a Bard." Sydney Review of Books. 4 December 2020, https://tinyurl.com/scm9tsmb. Accessed 20 April 2021.

Masterson, John. "'Don't tell me this isn't relevant all over again in its brand new same old way': imagination, agitation, and raging against the machine in Ali Smith's Spring." Safundi 21.3 (2020): 355-372. https://doi.org/10.1080/17533171.2020.1776961.

Mbembe, Achille. Necropolitics. Trans. Steven Corcoran. Durham: Duke Up, 2019.

Norris, Pippa, and Ronald Inglehart. Cultural Backlash: Trump, Brexit, and Authoritarian Populism. Cambridge: Cambridge UP, 2019.

O'Rourke, Kevin. A Short History of Brexit: From Brentry to Backstop. London: Pelican, 2019.

Orwell, George. Nineteen Eighty-Four. London: Penguin 2013.

O’Toole, Fintan. Heroic Failure: Brexit and the Politics of Pain. New York: Apollo, 2019. E-book.

Rau, Petra. “Autumn After the Referendum.” Brexit and Literature: Critical and Cultural Responses. Ed. Robert Eaglestone. New York: Routledge, 2018. 31-43.

"Refugee Tales." Literature Cambridge. https://www.literaturecambridge.co.uk/refugee. Accessed 20 April 2021.

Saunders, Robert. "Brexit and Empire: 'Global Britain' and the Myth of Imperial Nostalgia." The Journal of Imperial and Commonwealth History 48:6 (2020): 1140-1174. https://doi.org/10.1080/03086534.2020.1848403

Shaw, Kristian. "BrexLit." Brexit and Literature: Critical and Cultural Responses. Ed. Robert Eaglestone. New York: Routledge, 2018. 15-30. 
Smith, Ali. Autumn. London: Hamish Hamilton, 2016.

---. Winter. London: Hamish Hamilton, 2017.

---. Spring. London: Hamish Hamilton, 2019.

---. Summer. London: Hamish Hamilton, 2020.

Smith, Zadie. “Fences: A Brexit Diary." Feel Free: Essays. London: Penguin, 2019. 20-34.

\section{| Abstract}

Tomasz Dobrogoszcz

Are We In This Together?: The Polarisation of the British Society and the Marginalisation of Otherness in Ali Smith's Seasonal Quartet

Ali Smith's seasonal quartet-Autumn, Winter, Spring, Summer-was written and published at lightning speed, between the 2016 Brexit referendum and Britain's effective departure from the EU in 2020. The article examines how the novels engage with the issue of Brexit, as they become the chronicle of a grinding cultural process and critically confront the transformation of the British nation. I survey various psychological factors related to the polarisation of the British nation and investigate Smith's presentation of the way in which the populist propaganda of menace produced by the right-wing media leads to marginalising Otherness. Employing the nomadic theory of the subject developed by Rosi Braidotti, I analyse Smith's literary strategies used to represent not only post-truth manipulation and institutionalised British xenophobia, but also the actions of people who resist them.

Keywords: Ali Smith; Brexit; Autumn; Winter; Spring; Summer; the Other; populism; post-truth

\section{| Abstrakt}

Tomasz Dobrogoszcz

Czy jesteśmy tu razem? Polaryzacja społeczeństwa brytyjskiego i marginalizacja Inności w tetralogii Ali Smith inspirowanej porami roku

Tetralogia Ali Smith inspirowana porami roku - Jesień, Zima, Wiosna, Lato - została napisana i opublikowana w ekspresowym tempie, pomiędzy referendum w sprawie Brexitu w 2016 roku a ostatecznym opuszczeniem uE przez Wielką Brytanię w roku 
2020. Artykuł analizuje sposoby literackiego przedstawienia brexitu w powieściach Smith, skupiając się na wyznacznikach ukazanego przez pisarkę niepokojącego procesu kulturowego oraz drastycznych zmianach zachodzących w brytyjskim społeczeństwie. W tekście dokonuję przeglądu czynników psychologicznych powodujących polaryzację narodu brytyjskiego oraz badam, w jaki sposób proza Smith ukazuje wpływ populistycznej propagandy zagrożenia na marginalizację Inności. Wykorzystując nomadyczną teorię podmiotu sformułowaną przez Rosi Braidotti, omawiam strategie literackie wykorzystane przez autorkę do ukazania zarówno manipulacyjnego potencjału postprawdy i zinstytucjonalizowanej brytyjskiej ksenofobii, jak i działań osób, które się im przeciwstawiają.

Słowa kluczowe: Ali Smith; brexit; Jesień; Zima; Wiosna; Lato; inność; populizm; postprawda

\section{About the Author}

Tomasz Dobrogoszcz, PhD., D.Litt., Department of British Literature and Culture, University of Łódź. His main fields of research include contemporary British and postcolonial literature, poststructuralism, psychoanalytical literary theory, and posthumanist studies.

Published works include: Family and Relationships in Ian McEwan's Fiction: Between Fantasy and Desire (Lexington Press, 2018); "Eating Men Is Wrong: Empathy, Femininity and the Abject in Under the Skin." In: Michel Faber: Critical Essays (Gylphi, 2020); "The planet heals itself: the overkill of Homo sapiens in contemporary literature" (European Management Journal 35.6 2017).

Edited works include: Reading Graham Swift (Lexington Press, 2020); Nobody Expects the Spanish Inquisition: Cultural Contexts In Monty Python (Rowman and Littlefield, 2014).

E-mail: tomasz.dobrogoszcz@uni.lodz.pl

ORCID: 0000-0002-4579-7143 